\title{
La Sociedad Criolla Dr. Elías Regules: el resurgimiento gauchesco en Uruguay (1935-1944)
}

Matías Emiliano Casas

Universidad Nacional de Tres de Febrero / Consejo Nacional de Investigaciones Científicas y Técnicas, Argentina.

Correo electrónico: mecasas@untref.edu.ar

Artículo recibido: 04 de abril de 2019 Aprobación final: 13 de septiembre de 2019

\section{Resumen}

La primera asociación tradicionalista de América se fundó en 1894 bajó la denominación de "Sociedad Criolla". Elías Regules fue el gestor de ese movimiento que se transformó en referencia ineludible para el criollismo rioplatense. Este artículo se focaliza en la dinámica experimentada por la agrupación a partir de mediados de la década del treinta luego de un interregno provocado por el fallecimiento de su fundador. Se considera que tanto las condiciones generadas por el golpe de Estado de 1933 como la vinculación con tradicionalistas argentinos vigorizaron el renacimiento de "La Criolla" en Montevideo y promovieron un resurgimiento gauchesco en el Uruguay. A partir de los estatutos, reglamentos y libros evocativos editados, la prensa masiva y la revista Cimarrón, su órgano de difusión, se pretende dar cuenta de la refundación de la Sociedad Criolla Dr. Elías Regules. Se analiza cómo impactó ese proceso en las narrativas originarias de la agrupación, en las modalidades prácticas, en los vínculos con instituciones locales, en los diálogos con las agrupaciones argentinas, y en las proyecciones hacia la sociedad uruguaya. 


\title{
Dr. Elías Regules Creole Society: The Gaucho Resurgence in Uruguay (1935-1944)
}

\begin{abstract}
The first traditionalist association of America was founded in 1894, under the name of "Sociedad Criolla". Elias Regules was the manager of that movement that became an inescapable reference for the Rio de la Plata criollism. This article focuses on the dynamics experienced by the group from the mid-thirties after an interregnum generated by the death of its founder. I consider that both the conditions generated by the coup d'etat of 1933 and the link with Argentine traditionalists invigorated the revival of "La Criolla" in Montevideo and promoted a gaucho resurgence in Uruguay. Through the statutes, regulations and edited evocative books, along with the mass press and the magazine Cimarrón, its official publication, we intend to show the refoundation of the Sociedad Criolla Dr. Elías Regules. We analyze, then, how this process impacted the original narratives of the group, the practical modalities, the links with local institutions, the dialogues with the Argentine groups, and the projections towards Uruguayan society.
\end{abstract}

Keywords: Uruguay, traditionalism, Argentina, Sociedad Criolla.

\section{Introducción}

En el escenario finisecular montevideano se fundó la primera agrupación tradicionalista de América, bajo la denominación de Sociedad Criolla. Se trataba de una experiencia embrionaria que había surgido desde la iniciativa del Dr. Elías Regules y un grupo de figuras artísticas ligadas primariamente al universo del teatro y del circo criollo. El 25 de mayo de 1894 se constituyó como una fecha bisagra para el criollismo rioplatense y, con el devenir del tiempo, los "gauchos" de "La Criolla" se consolidarían como referencia telúrica ineludible para la región.

Los estudios que se centraron en la literatura gauchesca, las representaciones del gaucho, los procesos identitarios y el folklore en Uruguay han reparado tangencialmente en la influencia del grupo de Regules. Si bien todos contemplaron menciones o referencias medianamente rigurosas sobre la Sociedad Criolla, aún no se han presentado investigaciones particulares que profundicen en la composición, los vínculos políticos y los procesos particulares atravesados por la agrupación. Ángel Rama (1976) le otorga una relevancia sustancial a la fundación de la Sociedad Criolla. En efecto, al repasar las cuatro etapas que el autor designa atendiendo el vínculo de los textos gauchescos con los contextos políticos, se concluye en 1894. El componente denunciante de la gauchesca habría dado paso a una nueva fase que quedaba por fuera de la periodización del autor. La institucionalización de la tradición, "encarnada" en la asociación, abriría una nueva etapa hacia la mitificación del gaucho. 
En ese sentido, la interpretación de Rama que liga las experiencias de la Sociedad Criolla con el "lirismo criollista uruguayo" se ha sedimentado (Achúgar, 1980). La extinción de la condena social y de las denuncias a los poderes políticos de turno a partir del surgimiento de la agrupación capitalina ha sido puesta en cuestión en nuestras investigaciones anteriores. En un trabajo sobre la revista El Fogón, publicación vinculada con La Criolla en los primeros años de su funcionamiento, hemos analizado una serie de críticas y acusaciones, principalmente durante la presidencia de Juan Idiarte Borda, ligadas al reclutamiento forzoso en los campos y a la ausencia del Estado en materia educativa (Casas, 2018). No obstante la tónica denunciante de algunos pasajes de la revista sobre la situación contemporánea de los campesinos uruguayos, la asociación estuvo lejos de reproducir esos discursos en sus programas sociales y sus fiestas públicas.

Su propuesta, más bien, se insertaba en un Uruguay en vías de modernización social, económica y política. Gerardo Caetano (2010) explica que las generaciones del 900 y del Centenario encontraron en las primeras décadas del siglo XX las condiciones para completar el "primer modelo de configuración nacional". Se trataba de un proyecto integrador, surgido desde el Estado a partir de la experiencia del primer batllismo. La eficacia política de José Batlle y Ordoñez al frente de la presidencia uruguaya promovió un proceso de "endointegración" con un "perfil universalista”, propio del Partido Colorado. Como señala Carolina González Laurino (2001), el "Uruguay modelo" del batllismo era cuestionado por el Partido Blanco en términos de apertura identitaria. En ese punto, Caetano (1992) realiza un esquemático discernimiento partidario en orden a la concepción de las identidades nacionales: por un lado identifica en el Partido Colorado un predominio de lo que denomina "uruguayanidad". Es decir, una matriz cosmopolita asentada en valores universales sin una clara distinción entre lo "nacional" y lo "foráneo". En contraste el Partido Blanco aparece vinculado con la noción de "orientalidad". Para ese caso la identidad nacional quedaba arraigada en lo telúrico en detrimento de los aportes de la "civilización europea". La perspectiva de Caetano permite aproximar vinculaciones políticas posibles para los tradicionalistas, como se verá más adelante.

Las disputas partidarias fueron retomadas por Carla Giaudrone (2008) a partir de su análisis sobre las representaciones iconográficas del gaucho en El libro del centenario del Uruguay, 1825-1925. Se trataba de una publicación privada que había sido respaldada por políticos vinculados con la Asociación Patriótica, agrupación vinculada con La Criolla. Pese a la falta de apoyo del presidente de la República, José Serrato, y del resto del batllismo, la obra fue presentada como una "publicación oficial” en 1926. Allí se recupera al gaucho como un arquetipo nacional y se lo presenta bajo una sucesión de imágenes que perfilan una seriación evolutiva para consagrarlo con un óleo de Juan Manuel Blanes en una representación idealizada del campesino uruguayo.

Con el golpe de Estado que sacó al batllismo del poder en marzo de 1933, el mundo rural como reservorio de la nacionalidad cobró un nuevo impulso. La propuesta cosmopolita e integradora de los sectores batllistas, dejó paso a una "posición 
tradicionalista” para sustentar los orígenes de la identidad nacional (Porley, 2019). La hipótesis de este trabajo es que el proceso de crecimiento y expansión que transitó la Sociedad Criolla desde 1935 estuvo acompasado por esos cambios político-culturales y fomentó la cristalización de un "Uruguay gaucho". Al mismo tiempo, creemos que esa consolidación no alcanza una cabal comprensión sin advertir la influencia de los tradicionalistas argentinos que gestaron lazos de reciprocidad con los miembros de La Criolla.

En Argentina, la figura del gaucho ha sido rigurosamente estudiada desde diferentes perspectivas. Como señaló Raúl Fradkin (2003) el "arquetipo mítico del gaucho" está en permanente reformulación y constituye un proceso abierto. Adolfo Prieto (1988) mostró las funcionalidades y las tensiones que había generado el movimiento criollista a partir de la proliferación de la literatura de folletín hacia finales del siglo XIX. Los gauchos levantiscos, como Juan Moreira, habían generado tanto la aclamación popular como las reacciones de las clases dirigentes y de las élites letradas que cuestionaban el fenómeno folletinesco. Como ha revisado Ezequiel Adamovsky (2019), la circulación de esa literatura de fácil lectura y costo barato perduró hasta mediados del siglo XX. En paralelo, descle el Estado se ensayaron iniciativas para amansar y domesticar la representación del gaucho. Alejandro Cattaruzza y Alejandro Eujanian (2002) reseñaron las disputas políticas suscitadas en la década del treinta a partir del proyecto para emplazar un monumento a José Hernández. En otros estudios, advertimos la continuidad de las contiendas por la apropiación partidaria del gaucho y las derivaciones de la Fiesta de la Tradición celebrada oficialmente desde 1939 (Casas, 2016). Más allá de la extensión de la literatura generada en Argentina, esos trabajos carecen de un enfoque regional que permita integrar los procesos desplegados en Uruguay en orden a la restitución gauchesca.

Una excepción a destacar es el estudio de Ercilia Moreno Chá (2016) sobre las trayectorias, repertorios y conexiones entre payadores rioplatenses. El recorte cronológico aquí establecido habilita el diálogo con esa investigación porque se considera que la perspectiva regional constituye un prisma sustancial para el abordaje del tradicionalismo, tanto en la Argentina como en el Uruguay. Aun cuando se trate de temáticas arraigadas en discursos sobre la patria, lo nacional y la orientalidad, es dable contemplar la circulación rioplatense de esos procesos para analizar los cruces, las tensiones y las resignificaciones, tanto simbólicas como prácticas. En ese punto, este trabajo pretende focalizar en el entramado constituido por agrupaciones tradicionalistas de ambos márgenes del Plata durante el período, para develar el impacto de esas conexiones en el resurgimiento gauchesco uruguayo.

A partir de los estatutos, reglamentos y libros evocativos editados se pretende dar cuenta del resurgimiento de la Sociedad Criolla Dr. Elías Regules. A su vez, la consulta de la prensa periódica uruguaya permite vislumbrar la extensión del rebrotecer gauchesco a mediados de la década del treinta. Se analiza, entonces, cómo impactó ese proceso en las narrativas originarias de la agrupación, en las modalidades prácticas, en los vínculos con instituciones locales, en los diálogos 
con las agrupaciones argentinas, y en las proyecciones hacia la sociedad uruguaya. Además de los documentos señalados, la revista Cimarrón, fundada como órgano de difusión de la agrupación en 1935, se erige como una fuente primordial. En sus trabajos sobre la literatura posgauchesca, Pablo Rocca (2000) analizó los ataques al realismo campesino que comenzaron a esbozar las vanguardias narrativas uruguayas desde los años treinta, por ejemplo a través del semanario Marcha. Cimarrón, atenta a ese contexto, adquirió un tono de cruzada a favor del tradicionalismo rural que determinó la difusión de actividades, asociaciones, literatura, crónicas y editoriales fundamentales para el objeto de estudio de este trabajo.

\section{Los tiempos fundacionales}

El acta constitutiva de la Sociedad Criolla de Montevideo explicita que el día 25 de mayo de 1894 se reunieron un grupo de personas en el circo-teatro de la compañía Scotti-Podestá, emplazado en la capital uruguaya como parte de sus habituales giras por las ciudades rioplatenses, para fundar la nueva agrupación a iniciativa del Dr. Elías Regules. En rigor, la propuesta había circulado el día anterior a partir de una fiesta criolla realizada en Piedras Blancas y de una cabalgata por la avenida 18 de Julio en el centro montevideano. En la primera asamblea de las institución se dejaron sentadas las bases en cuanto a sus objetivos y a la composición de su comisión directiva (Sociedad Criolla. Libro Institucional, 1991).

Por "aclamación" fue designado Regules como presidente de la agrupación de manera unánime. Se trataba de un joven cirujano que había desarrollado una experiencia asociativa en el seno de los claustros académicos promoviendo la fundación de la Sociedad Universitaria en 1875 (Carámbula de Barreiro, 1987). Luego de haber dictado clases de Anatomía, Higiene y Medicina Legal, llegó a ser electo para el Decanato de la Facultad de Medicina en 1889. Además, su labor en el campo de la salubridad se había destacado por sus intervenciones durante las epidemias de cólera y sus presentaciones en los congresos sanitarios de la región. En paralelo a su fructífera carrera profesional, Regules fue cultivando un celo particular por las costumbres rurales y la reivindicación del gaucho como referencia identitaria para el Uruguay. Las estancias familiares en los campos de Durazno habrían promovido las primeras aproximaciones al universo gauchesco. Afición que se plasmaría luego en sus producciones escritas, principalmente en las obras teatrales Los Guachitos y El Entenao (Sociedad Criolla. Libro Institucional, 1991). Esos antecedentes, más el respaldo de su tío Juan Risso, quien cedería su quinta para las reuniones durante los primeros años, determinaron el liderazgo de Elías Regules.

El resto de los cargos de la Comisión fueron dirimidos por el voto de los treinta y tres socios fundadores. El número total no era menor y, como se verá más adelante, serviría para azuzar la ligazón de La Criolla con la historia patria uruguaya. En la vicepresidencia fue electo Orosmán Moratorio. No era otro que el famoso "Julián Perujo", afamado escritor en el entorno criollista. Su reconocimiento también 
llegaba de la mano de sus producciones teatrales como Juan Soldao (Silva Valdez, 1960). A partir de 1895, sería co-director del periódico El Fogón, la publicación más relevante en el ambiente gauchesco de la época. La nómina de funcionarios continuaba poniendo en escena las relaciones con el mundo teatral, Francisco Pisano, autor de Nobleza Criolla, ocupaba la tesorería de la asociación. Entre los fundadores, el propio José Podestá dejaba asentada su firma para dar forma a los treinta y tres iniciadores.

De acuerdo a los estatutos, La Criolla estaba destinada a: "fomentar y rendir culto a la reacción iniciada en favor de nuestras costumbres nacionales" (Sociedad Criolla. Estatutos, 1928, 3). En ese punto, cabe subrayar el carácter reactivo que estaba motivado por la lectura amenazante que realizaban de su sociedad contemporánea. La pretendida identificación entre las costumbres reivindicadas y las "costumbres nacionales" es otro de los aspectos contundentes en la declaración. Según el enunciado La Criolla se establecía como refugio y bastión de la nacionalidad uruguaya.

Si el primer artículo presentaba someramente el campo de acción, el segundo mostraba un carácter restrictivo tendiente a desvincular a la agrupación de proselitismos religiosos o políticos. Esa condición se sedimentó como una característica común en las agrupaciones tradicionalistas fundadas posteriormente. Empero, no se trataba de una innovación particular de la Sociedad Criolla. Por citar solo un ejemplo, en abril de 1894 se había fundado en Punta Carretas la Sociedad Recreativa de los 33. El artículo 19 del reglamento para socios esbozaba: "Se prohíbe terminantemente hablar de política y de religión" (Sociedad Recreativa de los 33. Reglamento, 1894, 6). Se trataría más de una declaración de autonomía en orden a la prevención de conflictos de índole ideológico entre los socios de agrupaciones que de un componente exclusivo de los centros tradicionalistas. Las prohibiciones instauradas en los estatutos y reglamentos quedaron fijados en la letra pero, como mostrará el caso de La Criolla, no estuvieron exentos de intersticios y reformulaciones en la práctica.

Los tiempos fundacionales no solo marcaron parámetros rígidos para las temáticas posibles y el carácter de sus actividades, también la composición societaria quedaba claramente restringida. La Sociedad Criolla no contaría con más de 150 socios activos, según sus reglamentos aprobados y vigentes durante la primera década del siglo XX. En el caso de habilitarse una vacante, por renuncia, expulsión o fallecimiento de un miembro, el nuevo aspirante debía atravesar un engorroso proceso burocrático para ser admitido. En primer lugar, debía estar vinculado a la agrupación en la categoría de socio suscriptor con una antigüedad no menor a un año. Además, debía contar con la recomendación por escrito de dos socios activos, que luego expondrían ante la asamblea la defensa de la postulación de manera oral. Finalmente, la Comisión Directiva seleccionaba entre los postulantes y se aprobaba por votación. La participación en las fiestas también mostraba un sesgo restrictivo. A los almuerzos y bailes realizados en las estancias que funcionaban como sede social, y luego en el "rancho" propio desde 1904, solo se podía invitar a la misma persona (ajena a la agrupación) una vez cada dos años. 
Ante esas limitaciones, voluntariamente establecidas, la Sociedad Criolla mostraba un perfil endogámico. Al tiempo que pretendían intervenir públicamente en la capital de la República para revitalizar el culto al gaucho y las tradiciones rurales con diferentes actividades, la posibilidad de integrarse a la agrupación quedaba severamente restringida a un grupo minoritario. Esa "élite" tradicionalista se autolegitimaba como auténtica portadora de las tradiciones rioplatenses y confirmaba su condición en cada una de sus fiestas. En uno de sus discursos más recuperados, Elías Regules exhortaba: "Aquí no se fomentan costumbres populares ni se cultivan pretensiones de habilidades exclusivas del elemento rural. No hay compadres ni camperos" (Sociedad Criolla. Libro Institucional, 1991, 10). La agrupación se mostraba escindida de las "costumbres populares" en la voz de quien fuera su máxima referencia.

Las palabras de Regules fijaban los contornos de la asociación e intentaban definirla en el seno de una Montevideo en proceso de modernización. Como mostramos en trabajos anteriores (Casas, 2018), durante los primeros años de La Criolla se realizaron notorios esfuerzos por confirmar su asimilación con los "convencionalismos del medio civilizado", que llevaron incluso a promover el tradicionalismo de "frac y guante blanco" por parte de su presidente. No es menester de este artículo adentrarse en las tensiones internas que generó la postura de la Comisión Directiva al respecto, pero sí destacar que esos intentos eran consecuencia directa de las críticas y cuestionamientos recibidos desde diferentes sectores. En el diario La Razón, el 3 de septiembre de 1894 se cuestionó la fundación de la sociedad argumentando que ponían de relieve atavismos ya superados por la "influencia benefactora de una civilización superior" (Sociedad Criolla. Sus bodas de plata, 1919, 9). La burla del "Montevideo elegante" quedó sellada en las memorias de La Criolla y de aquellos que reivindicaron sus aportes a la sociedad uruguaya. Luis Alberto de Herrera, uno de los políticos más significativos del siglo XX, expresaba en un homenaje a Elías Regules: "Los fogones de su Criolla, tan hostilizada y tan injustamente ofendida, parecieron brasas del infierno. El mal de moda era la renegación sistemática de lo nativo" (Iturria, 2014, 65). Por su parte, el fundador se encargó recurrentemente de enumerar las tempranas condenas que los sindicaban como sembradores del retroceso. Frente a ese panorama, la asociación sostuvo como una de sus prioridades mostrarse completamente adaptada a las transformaciones de la época.

En los festejos por las bodas de plata, en 1919, se confirmaron varios de los caracteres estructurantes del centro tradicionalista. Un halo de triunfalismo marcó la tónica del programa y de los discursos pronunciados. Las reseñas de la fiesta recordaban a los primeros socios que habían resistido "a una inmensa mayoría de compatriotas ganados a la causa estúpida de la europeización irreflexiva" (Sociedad Criolla. Sus bodas de plata, 1919, 27). El aniversario resultaba un momento propicio para corroborar la victoria de La Criolla: "Hoy ya no se desprecia al gaucho". Las coberturas de la prensa gráfica abonaban la celebración. El diario La Mañana, por ejemplo, afirmaba: "Si La Criolla ha triunfado se debe en muy buena parte a Elías Regules" (Citado en Sociedad Criolla. Sus bodas de plata, 1919,31). El periódico era canal de expresión del sector político antibatllista 
liderado por José Manini Ríos, quien sería funcionario de la dictadura iniciada en 1933, y funcionó como caja de resonancia de las actividades realizadas por los tradicionalistas. El presidente inició aquella fiesta de 1919 obsequiando una nueva bandera a la agrupación. El diseño, fiel al original, presentaba cuatro franjas azules verticales en fondo blanco, atravesadas por una diagonal roja, en homenaje a José Gervasio Artigas, donde rezaba el nombre de la institución (Sociedad Criolla. Estatutos, 1928).

Además de las actividades realizadas el 25 de mayo, se editó un libro especial donde se recuperaba el recorrido de los 25 años de la agrupación. En esas reseñas se esbozaban algunos indicios que permitían sustentar la concepción triunfalista de su trayectoria. En diciembre de 1904 habían inaugurado su propio local luego de la compra de un terreno en la zona de Atahualpa, al norte de Montevideo. La sede se mantuvo hasta la década del cuarenta cuando lograron trasladarse a una estancia más grande. La Criolla, además, comenzó a participar en las fiestas municipales de la capital uruguaya. Es factible que las corridas de sortija en el hipódromo y los espectáculos de música y baile para los teatros capitalinos hayan incrementado la noción triunfalista de los asociados. Los gauchos eran protagonistas convidados por la Comisión de Fiestas de Montevideo lo que resaltaba el cambio de actitud con respecto a la "vergüenza" finisecular.

En 1913, además, habían concretado un anhelo que se había difundido desde los comienzos de la institución. En la sede se inauguró un monumento a Artigas realizado por el escultor italiano Félix Morelli que contenía la leyenda "grande y nuestro", permanentemente revisitada desde las publicaciones de la agrupación. El emplazamiento no era menor si se contempla que el proyecto oficial del Estado para evocar al prócer, resuelto por decreto en 1907, aún se encontraba en tratativas y sería inaugurado recién en 1923 (Tomeo, 2015). A la tarea monumentaria y festiva, se le agregaba un tercer elemento que daba cuenta del posicionamiento que había tomado La Criolla en el ámbito tradicionalista del Río de la Plata: los vínculos, conexiones y referencias con instituciones argentinas. Entre 1901 y 1903, una delegación de la Comisión Directiva viajó a Buenos Aires para participar activamente de reuniones de la "Sociedad Criolla" de esa ciudad. Si bien los datos al respecto son fragmentarios e inconclusos, pareciera que se trataba de uno de los tantos centros tradicionalistas que proliferaron a comienzos del siglo XX en la capital argentina y que fueron recuperados, en primera instancia, por las investigaciones del antropólogo Robert Lehmann Nitsche (1917).

Lejos de quedar anclada como una experiencia pretérita, los intercambios con argentinos se incrementaron con el tiempo. El 25 de mayo de 1917 se realizó un evento de gala en homenaje a la República Argentina. Entre los eclécticos representantes del país vecino se encontraban: el político Francisco Barroetaveña, el jurista Guido Lavalle, y el médico Benjamín D. Martínez. El programa típico del aniversario de La Criolla se vio transformado por símbolos, iconografía y números artísticos con directa alusión a la Argentina. Conformaba un antecedente para lo que acontecería décadas adelante en el marco del renacer tradicionalista 
rioplatense. La última alusión al respecto se realizó durante la fiesta que conmemoraba las bodas de plata. Elías Regules emparentó la "gesta" de la novel Liga Patriótica Argentina con lo que habían iniciado en el circo de Scotti-Podestá hacía 25 años. Incluso citó palabras de Manuel Carlés con respecto al pasado como noble blasón para los países del Plata. El presidente de la Liga era referenciado como "distinguido cultor del tradicionalismo" y así aplaudido por los gauchos en Montevideo. Ana María Rodríguez Ayçaguer advirtió sobre los temores que había despertado en los sectores conservadores uruguayos el conflicto en Buenos Aires. La Semana Trágica agitó reclamos sindicales en Montevideo lo que generó una atmósfera particularmente inquietante (Rodríguez Ayçaguer, 2008). En ese contexto, la lectura de Regules identificando al incipiente movimiento como parte de las agrupaciones que se fundamentaban en el culto al gaucho y las tradiciones rurales era, cuanto menos, poco precisa.

En resumen, los paralelos con la Argentina pasaron a conformar un ingrediente permanente para la construcción de una narrativa propia. En ese punto, la publicación especial de 1919 se erige como un documento obligado para revisar el relato generado. Por un lado, cada contacto con instituciones foráneas permitía subrayar el carácter de "matriarca de América" de la Sociedad Criolla. La capacidad para establecerse como la vanguardia del tradicionalismo americano fue incrementando con los años y pasó a configurarse como principio básico de sus discursos. Por otro lado, Elías Regules también extendía su reconocimiento como patriarca de esa tradición. La muestra folklórica recopilada por los docentes argentinos en 1921, por ejemplo, dieron cuenta de la difusión de sus poesías en diversas provincias de ese país (Iturria, 2014). En Uruguay, era elevado junto al panteón de héroes nacionales ya consagrados por la historia tradicional. El recuerdo de los treinta y tres liderados por Lavalleja y Oribe en 1825 se confundía con aquellos socios fundadores que habían dado origen a La Criolla. El juramento a la bandera, la reseña de cada episodio bélico de la historia nacional, los proyectos para erigir un monumento a Lavalleja, eran otros de los condimentos utilizados para confirmar el carácter patriótico de la asociación.

Un último elemento a considerar se resume en la utilización del perfil universitario de Regules para extenderlo a toda la agrupación desde el tiempo de su fundación. Así, no vacilaban al rememorar al "grupo de universitarios" que tomaron como insignia la bandera que había comenzado a levantar José Podestá con su circo criollo. Se considera que esa ligazón con el espacio académico nutría la noción de asimilación a la "civilización" en ciernes. Regules funcionaba como un exponente testimonial. Su trayectoria lo llevaría al rectorado de la Universidad de la República en 1922, cargo que, entre otras oportunidades, le permitiría oficiar de anfitrión de Albert Einstein en 1925. Al mismo tiempo la faceta universitaria de los "gauchos" se ponía de relieve como muro de contención ante las críticas recibidas. La civilidad de La Criolla no quedaba solo en la retórica sino que se ocupaba de mostrarla también en sus actividades. El 25o aniversario cerró con baile de one-step, two-step y tango, estilos musicales inconcebibles para el período de resurgimiento que se desarrolló durante la década del treinta (Sociedad Criolla. Sus bodas de plata, 1919). 


\section{El resurgimiento en los años treinta}

Elías Regules falleció el 4 de noviembre de 1929. Dos años antes se había inaugurado el monumento al gaucho en el centro de Montevideo. El proyecto había surgido del seno de la Federación Rural a partir de la iniciativa de Alejandro Gallinal, dirigente del Partido Nacional y funcionario cultural durante la década del treinta. Si no se trataba de una labor exclusiva de la Sociedad Criolla, había quedado suficientemente representada ya que Regules presidió la Comisión Especial constituida para el evento. Hasta el momento de su muerte, el patriarca estuvo a cargo de la agrupación tradicionalista que años más tarde llevaría su nombre. Su deceso fue el inicio de un interregno para la agrupación, que quedó sellado con el calificativo de "la noche". ${ }^{2}$ A la pérdida de Regules se le sumaron una serie de dificultades económicas que no terminan de esclarecerse a partir de los documentos conservados. De acuerdo a los testimonios de la época se habrían relacionado a cargas impositivas sobre los terrenos auspiciadas por la intendencia de Montevideo. Ambos episodios se contrastaban con el tiempo de auge y esplendor transitado en las primeras décadas del siglo XX. El tiempo de retracción duró hasta 1935 cuando tomaron la iniciativa de la Comisión, el Dr. Tabaré Regules, hijo del extinto escritor, y el Dr. Justo Alonso.

La noche no había llegado solo para los tradicionalistas. En las elecciones presidenciales de 1930, Gabriel Terra había triunfado con el apoyo del batllismo, pero prontamente mostraría un acercamiento con sectores conservadores. Los primeros años de su gobierno estuvieron marcados por los efectos de la crisis económica. La oposición, apuntalada por la Federación Rural, conformó el Comité de Vigilancia Económica. Desde allí se fomentaron acusaciones y sospechas sobre el influjo migratorio, la vinculación entre el batllismo y el comunismo, e incluso se apoyó una salida golpista para barrer con los elementos de esa facción del Partido Colorado presentes en el Consejo Nacional de Administración (Barrán, 2004). Terra fue virando en sus políticas hasta alcanzar diversos puntos de encuentro con algunos de los planteos del Comité. En 1932 se aprobó un proyecto para reprimir la "inmigración indeseable" y se azuzaron los vientos de supuestos complots comunistas. La detención ilegal del legislador José Lazarriaga fue un signo del clima de época. En marzo de 1933, el presidente, junto con sectores conservadores del Partido Nacional y antibatllistas del Partido Colorado, ejecutaron un golpe de Estado y clausuraron el parlamento y el Consejo Nacional (Ruiz, 2008).

La dictadura terrista adoptó medidas favorables a los intereses del campo. La "cruzada ruralista” no solo se sustentó en la legislación que estimuló el agro y la ganadería. El escenario rural fue recuperado en detrimento del cosmopolitismo citadino (Ruiz, 2008). Los cambios en las formas de patriotismo estuvieron apuntalados por la creciente intervención del Estado en materia cultural y por la intensificación de los símbolos patrios, las efemérides y los desfiles desde los ámbitos educativos (Porley, 2019). En paralelo, la animadversión al comunismo se exacerbaba y el presidente Terra rompía relaciones con la Unión Soviética (Jacob, 1983). 
En ese contexto, Tabaré Regules y Justo Alonso reanimaron la Sociedad Criolla. Los nuevos dirigentes compartían profesión en el ámbito de la salubridad y lazos familiares. Alonso se había casado con una de las hijas de Elías Regules y fue quien ocupó la presidencia en el período 1935-1936, secundado por Tabaré Regules, que ofició como vicepresidente y como director de la revista Cimarrón al tiempo de su fundación. Desde sus páginas se difundía asiduamente el resurgir criollo de la asociación y se pretendía hacerlo extensivo hacia toda la sociedad uruguaya.

En uno de los primeros editoriales de la publicación celebraban la independencia en marcha equiparando el renacer de la Sociedad Criolla con la "gesta" del Grito de Asencio. En ambos casos "el galope de los gauchos" habría impulsado un proceso de emancipación que aún se consideraba inconcluso. Lo destacable del relato era que esbozaba una frágil alusión a lo que sucedía en el resto del continente americano. Sin datos precisos, insinuaba que así como el "médico poeta” (por Elías Regules) había fomentado el tradicionalismo en el Uruguay, "en los demás países de América fueron dando su grito de Asencio". ${ }^{3}$ De hecho, para mediados de la década del treinta se podía reconocer un tiempo expansivo de las agrupaciones tradicionalistas en diversos países del continente. En Las metamorfosis del gaucho (Casas, 2017) analizamos la proliferación de círculos criollos en la provincia de Buenos Aires y la proyección hacia el interior del país. En México, se consolidaban las asociaciones charras a partir de, entre otras cosas, la consagración oficial del Día del Charro en 1933 (Pérez Montfort, 2003). En Chile, los huasos comenzaron a participar activamente en los festejos del 18 de septiembre y a organizarse en clubes para la práctica del Rodeo (Lago, 1953). En el sur de Brasil, los Centros de Tradições Gaúchas funcionaban rememorando las tradiciones rurales a través de actividades ecuestres y reuniones que años más tarde devendrían en congresos tradicionalistas nacionales (Zalla, 2018). Lo cierto es que, si bien los ejemplos se podrían continuar, la percepción plasmada desde Cimarrón era acertada.

El surgimiento de asociaciones durante la década del treinta se emparentaba, de modo general, en una lectura temerosa de la sociedad contemporánea. En cierto punto, las fundaciones evidenciaban un signo reactivo ante los perfiles que iban adquiriendo las grandes ciudades, fuese en el norte de América o en la zona del Río de la Plata. La reacción criolla estimulada desde la agrupación gestada por Regules dejó constancia de una serie de preocupaciones que combatieron con intensidad en cada manifestación pública.

Los discursos sobre lo "foráneo" se fueron reproduciendo desde los primeros tiempos de la agrupación. En la década del treinta se comenzaron a precisar los mayores temores al respecto y de eufemismos como "semillas exóticas" para delinear los peligros de la vida moderna se pasaron a referencias más concretas que tanto los socios de La Criolla como los lectores de Cimarrón podían identificar fácilmente. Como se mencionó más arriba no era un temor exclusivo de los tradicionalistas. El presidente de la nación, Gabriel Terra, aseguró que hacia 1934 el 
país se estaba convirtiendo en "una cloaca de degenerados procedentes de todas partes del mundo" (Jacob, 1983, 106). La modificación de la "ley de indeseables" en 1936 abonaba esas lecturas (Porley, 2019).

Una de las amenazas que denunciaron los gauchos fue el "neocriollismo". Se trataba de la caracterización forzada de las costumbres, la vestimenta y el modo de hablar campero por parte de los migrantes. La "fabricación de criollos" era denunciada como un mal a erradicar, aún a mediados de los años treinta. Uno de los mayores exponentes en esa cruzada fue el poeta Romildo Risso. En una reseña del problema afirmaba: "¡No es de creer que sangre rusa resulte criolla en América!". ${ }^{4}$

Las contundentes aseveraciones no surgían del seno de la Sociedad Criolla pero sí de un allegado que resultó puntal para las conexiones tradicionalistas rioplatenses. Risso contaba con el reconocimiento de "criollo legítimo" y así se lo hacían saber desde las páginas de Cimarrón luego de citar la salutación del poeta por el número inaugural. Sus escritos habitualmente formaban parte de las secciones literarias de la revista. Aún previo al encuentro personal con los miembros de la agrupación, Risso contaba con el auspicio de los tradicionalistas uruguayos que difundían sus trabajos con la misma intensidad con la que sucedía en Buenos Aires. En abril de 1936, visitó la sede de La Criolla y las tertulias no hicieron más que replicar las acusaciones contra los neocriollistas. El "paladín del sano y verdadero criollismo" era exaltado por su permanente intransigencia frente a las tendencias modernistas. ${ }^{5}$

Junto al neocriollismo, se esbozaba otra de las afrentas que tanto ocupaban a los tradicionalistas, y que se encontraba estrechamente vinculada a esas prácticas: los productos culturales masivos, generados principalmente por la industria norteamericana. De ese modo, Risso también era presentado como soldado ante la simbolización de "nuestro tipo regional con chiripá carnavalesco y chambergo partido" y ante "el influjo pernicioso de las películas gringas de Gardel”. ${ }^{6}$ No se trataba de una quijotada de la agrupación montevideana sino que para la época se podían hallar discursos similares en la región. Por ejemplo, la Asociación Folklórica Argentina tomó la temática como una de sus principales banderas. La prensa no especializada en la materia también se pronunciaba al respecto. Así, el diario La Mañana de la capital uruguaya atacaba a las "máscaras gauchas" inventadas en Hollywood y a los "absurdos ropajes que utilizaron para caracterizar a nuestros hombres de campo Gardel y otros artistas cinematográficos". ' La percepción sobre el avance de esas producciones dirigían el mensaje hacia caminos apocalípticos: "El cine ha concluido con nuestra tradición gauchesca". En efecto, el cine se imponía como un signo del avance de las multinacionales del espectáculo en el país y, desde ese perspectiva, era asimilado como una invasión tan peligrosa como la

4 (Diciembre de 1935), Cimarrón, Montevideo.

5 (Abril de 1936), Cimarrón, Montevideo.

6 (Abril de 1936), Cimarrón, Montevideo, p. 15.

7 Citado en (Marzo de 1936), Cimarrón, Montevideo, p. 20. 
inmigratoria. El mismo año de la crítica citada, en Montevideo se inauguró la sala Metro con capacidad para más de mil espectadores, signo de la expansión del séptimo arte en la capital (Jacob, 1983).

La Sociedad Criolla también mostró su oposición a otras tendencias de la vida moderna. El tango como producto y representación del arrabal se encontraba en el podio de las tribulaciones. Con frecuencia se lo vinculaba al rencor, se lo sindicaba por su estilo dormilón y se lo ligaba al consumo de cocaína. ${ }^{8}$ Los relatos que se publicaban en Cimarrón acompañaban la condena y, en algunos casos, graficaban de modo contundente el posicionamiento de los tradicionalistas.

En un cuento gauchesco titulado "Tango y Pericón: la carrera criolla" se presentaba la competencia entre dos caballos, un oscuro alazán, Tango, y un overo rosado, Pericón:

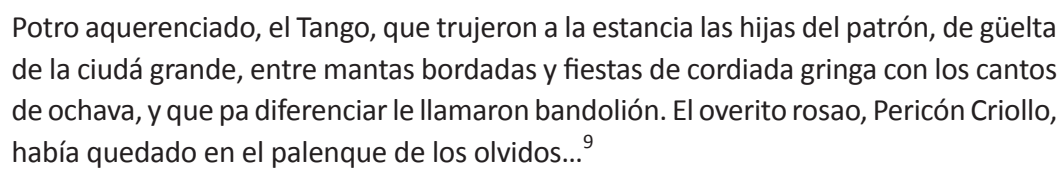

Luego de un inicio promisorio de Tango, "dopado con tuitas las drogas del cabaré y del arrabal", se vio sucumbir ante el empuje del overo, "sin morfina ni coca”. Así fue que "el Tango, hecho de infamias y resaca pura viruta de vicio y de cobardía, jué incapaz diaguantar el cimbronazo”. El paisanaje celebró la victoria de Pericón y olvidó al oscuro alazán. El último párrafo del cuento contenía una suerte de moraleja dirigida directamente al Tango donde lo acusaban de carecer de sol, olor a campo y trinar de zorzales para hacerse llamar criollo. ${ }^{10}$

Al tango se le sumaban las críticas a la gomina, el rouge, el copetín y la lista se extendía al calor de las nuevas costumbres citadinas que generaban alarmas incesantes. Incluso las formas de entretenimiento que no mostraban un arraigo telúrico eran denostadas desde las páginas de Cimarrón. El fútbol fue uno de los objetivos preferidos. Es válido recordar que los triunfos de la selección uruguaya en los juegos olímpicos de 1924 y 1928 habían sido utilizados por el batllismo en sus esfuerzos por nacionalizar a un conjunto poblacional heterogéneo (Rodríguez Ayçaguer, 2008). En esa línea, la construcción de estadios, la organización del mundial de 1930 e incluso las secuelas del triunfo del máximo galardón parecían incomodar a los tradicionalistas, que celosamente reclamaban esa atención para las competencias ecuestres. Mucho más atractivas que "ver patear una vejiga inflada para meterla en un trampero". ${ }^{11}$

8 (Mayo de 1936), Cimarrón, Montevideo.

9 (Noviembre de 1936), Cimarrón, Montevideo, p. 18

10 (Noviembre de 1936), Cimarrón, Montevideo, p. 19.

11 (Mayo de 1936), Cimarrón, Montevideo, p. 14 
Paradójicamente, los peligros identificados por la agrupación también se relacionaron con actividades a priori ligadas a sus intereses. Desde 1925, la municipalidad de Montevideo organizaba en el predio de la Asociación Rural la "Semana Criolla" con el propósito de fomentar el turismo en el tiempo de la celebración de las Pascuas cristianas (Moreno Chá, 2016). A partir de la doma, los desfiles y las payadas, el ambiente gauchesco se ponía en escena pero lejos de celebrarlo, en mayo de 1936, el Gaucho Florido (aparentemente David Dipetta), como también se lo designaba en la nómina de la asociación, focalizaba en la indumentaria para burlarse del chiripá verde de un "gaucho", la gorra vasca de otro, las camisas de seda y demás accesorios que encontraba irrisorios. Tampoco la jineteada de vacunos parecía formar parte de las actividades "legítimas" que proyectaban descle La Criolla, y por eso eran defenestradas las prácticas en el evento municipal.

El cuadro de situación, así descripto, no habilitaba mayores interregnos. Con Tabaré Regules a la cabeza la agrupación inició su proceso de reinvención con una retórica que apelaba a los tiempos fundacionales. Los más renombrados de aquellos treinta y tres vanguardistas eran evocados en las fiestas a partir de sus poemas, discursos, imágenes, etc. El propio Regules en un poema que reseñaba la celebración en La Criolla por el 25 de agosto aducía haber visto a su padre junto a Orosmán Moratorio y Alcides De María -otrora codirector de El Fogón y miembro de la Comisión Directiva- verseando en la velada. ${ }^{12}$ Tratando de convencer, y convencerse, de ese "espíritu fundacional" emprendieron la renovación de la agrupación que se dejó ver en diversas iniciativas, algunas de ellas disociadas de las premisas originarias.

En primer lugar, la ya denominada Sociedad Criolla Dr. Elías Regules promovió una campaña para alcanzar los 500 socios activos. De los 150 que se permitían como máximo en los primeros estatutos se pasó a la búsqueda intensa por extender los miembros y, junto con ellos, los ingresos. Para motivar la pesquisa de nuevos integrantes, los socios eran alentados a cooptar la mayor cantidad de aspirantes posibles. De ese modo, aquel que generara más socios nuevos obtendría un diploma de honor y, los cuatro que le siguieran, un almuerzo en agasajo. Más allá de lo económico, es dable considerar que el cambio de perspectiva con respecto al número de asociados se relacionaba también con el objetivo de extender el impacto de La Criolla en esa sociedad “amenazante". En febrero de 1942 se dirigieron al Ministro de Instrucción Pública y Previsión Social para solicitar la aprobación de la reforma de los estatutos. La limitación del número de socios activos quedaba sin efecto ante el incremento alcanzado fruto de esa iniciativa ampliatoria. ${ }^{13}$

Las convocatorias no solo se dirigieron a ampliar los cuadros societarios, también se fomentó la ligazón con la agrupación a través de concursos literarios de los que podían participar todos los uruguayos que lo desearan. En marzo de

12 (Septiembre de 1936), Cimarrón, Montevideo.

13 Nota firmada por Justo Alonso (presidente) y Luis Cravino (secretario), 24 de febrero de 1942. Sección de Archivo y Documentación del Instituto de Letras (SADIL), Facultad de Humanidades y Ciencias de la Educación, Universidad de la República, Montevideo. 
1936 presentaron dos líneas alternativas para composiciones: una invitación más amplia con el título "poesía nativa" y otra referida a la batalla de Sarandí como hito del proceso independentista. De acuerdo al criterio de los organizadores, la recepción de más de sesenta ensayos era un signo alentador. En junio se publicaron los resultados. El primer premio en poesía nativa se le asignó a una composición denominada “Gaucho", escrita por José María Magnou. El autor quedó vinculado a la agrupación y comenzó a participar asiduamente de las fiestas. Además, se estableció como un colaborador permanente de Cimarrón. El título de la composición que recibió el segundo premio era también "El gaucho" por lo que se puede proyectar un tono monocorde con respecto al contenido de los poemas presentados.

Los galardones referentes a los ensayos sobre la batalla de Sarandí quedaron vacantes. Al momento de argumentar la decisión se explicó que "ninguna poesía recibida fue digna de la trascendencia histórica del episodio". ${ }^{14}$ Entre el jurado se encontraba Tabaré Regules por lo que toda decisión parecía quedar en manos de los miembros de la Comisión Directiva. La conclusión del concurso cumplió los objetivos primarios que tendían a promocionar las actividades de La Criolla por fuera de su entorno y encontrar nuevos interlocutores para sumarlos a la cruzada tradicionalista. Al mismo tiempo, puso en evidencia que los que acudieron a la convocatoria lo hicieron más motivados por el aspecto nativista del concurso que por los temas de historia tradicional que se pretendieron revisitar.

Las nuevas letras de la Sociedad Criolla se integraron en un año de renovación en la dinámica festiva de la agrupación. Al ineludible programa por el aniversario cada 25 de mayo, se fueron instituyendo otras actividades públicas que se prolongaron en el tiempo. Entre otras, la velada artística del 12 de octubre y la fiesta criolla en el balneario Carrasco durante el verano. Si bien ambas develaban el interés de la Comisión por intervenir en la sociedad capitalina como “último bastión de la tradición”, los mecanismos utilizados eran diferentes. En el primer caso, parte de la recaudación del evento, que generalmente se realizaba en los teatros más importantes de Montevideo como el S.O.D.R.E, se destinaba a ejecutar una acción social y/o educativa en nombre de la agrupación. Esos programas comenzaron a reseñarse en periódicos de gran tirada que celebraban la solidaridad de los gauchos e incluso a transmitirse en vivo por radio. ${ }^{15}$ En el caso de Carrasco se intentaba "educar" al turismo local y regional en las genuinas tradiciones orientales aprovechando la convocatoria del balneario y ofreciendo allí un programa de actividades ecuestres y bailes folklóricos.

A juzgar por los resultados obtenidos, y por la pervivencia de las prácticas, habría significado un nuevo triunfo para los tradicionalistas. En 1936, se donó el dinero a la Asociación Uruguaya de Protección a la Infancia para ser destinado a la compra y reparto de 32 cunas y 3 equipamientos especiales para niños con necesidades particulares. Cada cuna llevaba grabado el nombre y el escudo de La Criolla. La

14 (Junio de 1936), Cimarrón, Montevideo, p. 23.

15 (12 de octubre de 1935), El Diario, Montevideo, p. 6. 
presencia de los gauchos quedaba sellada para, al menos, 35 familias que convivirían con los símbolos tradicionalistas. No se trataba de un detalle menor en tanto la preocupación por las nuevas generaciones era una postura indeclinable descle los tiempos fundacionales. Con el nuevo impulso se establecerían también vinculaciones con el ámbito educativo en pos de auspiciar actos en promoción del patriotismo. ${ }^{16}$

Otro de los signos testimoniales del resurgimiento de la agrupación fue el lanzamiento de Cimarrón en diciembre de 1935. La revista contenía en su portada la bandera de La Criolla, su lema "Tradición y Patria”, una imagen de Elías Regules a caballo y con indumentaria gaucha, y una frase del patriarca que rezaba: "Vivo feliz con sangre americana, yo no tengo vergüenza de mi raza". Claro que se trataba de la "raza" criolla y de una sangre más caucásica que india como se encargó de explicar en distintos discursos. Cimarrón se estableció como una de las herramientas más eficaces en el combate planteado frente a los males de la sociedad moderna. Se trataba de una revista mensual, de aproximadamente treinta páginas en blanco y negro con publicidades diversas y con secciones fijas relativas al mundo campero. Con el correr de los números se fue consolidando como una red de contención y expansión de los tradicionalistas rioplatenses a través de la presentación de poemas, cuentos, correspondencias y proyecciones al respecto. Además, constituía una ventana de aproximación hacia la Sociedad Criolla ya que en cada ejemplar se reseñaban sus principales actividades. En diciembre de 1936, al celebrar el primer año de Cimarrón, el editorial explicaba los optimismos que habían llevado adelante la empresa y celebraban victoriosos la "clarinada triunfal de la reivindicación gaucha". ${ }^{17}$

Esa clarinada se hacía oír también en otros registros. La agrupación fue posicionándose como una referencia recurrente en las publicaciones que cubrían las actividades culturales uruguayas. El diario El Día, vocero del batllismo, se ocupó de los aniversarios y las actividades realizadas por La Criolla en su resurgir. Claro que, aún cuando celebraban "el éxito de la vieja entidad nativista”, no perdían oportunidad de subrayar que el gaucho evocado se trataba de un elemento del pasado. ${ }^{18}$ Así afirmaban en referencia al gaucho del monumento: "está bien ahí [...] ya cumplió su misión”. ${ }^{19}$ La percepción del periódico vinculado al Uruguay cosmopolita daba indicios de la pervivencia de posturas desencontradas en orden a la restitución gauchesca.

Una pista de esos desencuentros -dado que ameritarían un trabajo particular- se puede vislumbrar en las revistas de las colectividades afrodescendientes. Desde sus páginas dieron cuenta de un cierto inconformismo con el creciente consenso de una identidad nacional resumida en el arquetipo gaucho. "Se vienen los gauchos!” alertaba una publicación sobre la ubicuidad de esa figura en los eventos

16 (Mayo de 1936), Cimarrón, Montevideo.

17 (Diciembre de 1936), Cimarrón, Montevideo, p. 2.

18 (3 de enero de 1937), El Día, suplemento dominical, Montevideo.

19 (4 de octubre de 1936), El Día, suplemento dominical, Montevideo. 
culturales y en la prensa uruguaya. ${ }^{20}$ En otros casos, se denunciaban los efectos sociales perniciosos de los gauchos de carnaval. ${ }^{21}$ En el diario La Razón, el de la polémica fundacional con Regules, sin alusiones directas se comentaban las "deformaciones de los mirones de ciudad" sobre el gaucho decimonónico. ${ }^{22}$ En consonancia, desde un enfoque académico Alberto Zum Felde $(1941,148)$ explicaba: "El paisano sentimental [...] el de los asados festivos de La Criolla nada tiene que ver con el paisano verdadero: es un ente retórico al que los cultos aficionados montevideanos prestaban su propia sentimentalidad literaria".

Desde la Sociedad Criolla no se acusó recibo de los cuestionamientos señalados. No obstante, se ejecutaron una serie de modificaciones con respecto al funcionamiento de la institución. Algunos de los parámetros que aparecían fijados a finales del siglo XIX se tornaron más laxos en la coyuntura de los años treinta. Si la política y la religión quedaban relegadas por estatuto de las experiencias de la asociación, en el promovido renacer gaucho sí encontrarían sus espacios. El presbítero José María Fontes Arrillaga, cercano a Elías Regules, fue poco a poco ocupando un rol de mayor relevancia en la agrupación hasta transformarse en un orador habitual de los festejos. ${ }^{23}$ Ante su fallecimiento en 1938, se realizó una sección especial en Cimarrón para recordar al "cura gaucho". En el mismo registro, se publicaron poemas y relatos vinculados al culto católico y a la participación de los gauchos en ellos como en el caso de "Virgencita e' Luján". ${ }^{24}$ En el caso de la política, las conexiones con los funcionarios terristas se evidenciaron en las fiestas organizadas por la asociación. Además, el vínculo con políticos del Partido Nacional se puso de relieve en las tratativas para instituir el Día de la Tradición, como se verá en el apartado siguiente.

Los integrantes de La Criolla fueron amoldando sus discursos a las necesidades de la época y, también, al impacto que generaba su resurgir en la sociedad montevideana. Así, la Semana Criolla tan cuestionada era entonces aplaudida y saludada como "la fiesta de la alegría para la que ha nacido el criollo". ${ }^{25}$ Entre otras cuestiones que se podrían haber modificado del festejo, una fue la participación orgánica de la agrupación en el diseño de competencias. Incluso, según lo que remitía en correspondencia un tradicionalista bonaerense, habían adquirido responsabilidad en el pronunciamiento de discursos durante la fiesta. La participación de criollos "legítimos" había dotado al otrora cuestionado festival en auténtica expresión criolla.

Si los vaivenes en diversos temas fue una característica de esta etapa, otros valores se mostraron inconmovibles ante el paso del tiempo. La tríada "patria, prenda y pingo" continuó siendo enaltecida como las mayores riquezas del gaucho

20 (Octubre de 1933), Nuestra Raza, Montevideo, p. 12.

21 (Marzo de 1947), Revista Uruguay, Montevideo, p. 9.

22 (9 de octubre de 1943), La Razón, Montevideo.

23 (Septiembre de 1936), Cimarrón, Montevideo.

24 (Enero de 1938), Cimarrón, Montevideo.

25 (Octubre de 1936), Cimarrón, Montevideo, p. 36. 
(Cimarrón, octubre de 1936). El lugar de la mujer y su equiparación (siempre subordinada) al valor que el jinete le otorgaba al caballo tenía su correlato en gran parte de las agrupaciones tradicionalistas americanas de la época. Por citar un caso, el lema de la Asociación Charros de Jalisco, fundada en Guadalajara en la década del veinte, era "Patria, mujer y caballo", en notoria consonancia con lo que se promovía desde el Río de la Plata (Palomar Verea, 2004).

Otra elemento inalterable se vinculaba a la representación idealizada del gaucho que ya para los años treinta ponía el acento en sus virtudes laborales en los campos, tanto para la ganadería como para la agricultura, y también en la ciudad. Los políticos que intervinieron en su consagración a partir del Día de la Tradición uruguaya también abonaban esa representación refiriendo al gaucho "manso, humilde y trabajador". Sin resignar sus atributos guerreros, en la Sociedad Criolla era erigido además como "constructor de las industrias que defienden la economía nacional". ${ }^{26}$ Así lo proclamaban al celebrar su 43o aniversario, intentando asimilar el culto al gaucho y la tradición con las transformaciones fabriles y los avances técnicos que, a diferencia de las modas señaladas más arriba, se consideraban positivos para el desarrollo económico y social.

La intención de ligar retóricamente al gaucho con la industria estaba en directa consonancia con otra de las preocupaciones permanentes de los miembros de La Criolla y del Gobierno de turno. En 1936, Justo Alonso pronunció un discurso revelador en la fiesta de fin de año de la agrupación. Es posible que en esa alocución haya primado su faceta política sobre su cargo de directivo tradicionalista. ${ }^{27}$ Lo singular fue la precisión de sus palabras y la virulencia empleada. Entre los asistentes se encontraba el presidente del Consejo de Instrucción Primaria, José Claudio Williman, uno de los principales impulsores del "nacionalismo a ultranza" descle la gestión educativa (Ruiz, 2008). Alonso, que había regresado de un viaje por Europa unos días antes del festejo, enunciaba:

\begin{abstract}
Si las corrientes exóticas procedentes de las vecindades del Asia llegasen a imponerse entre nosotros, el último baluarte de la patria que tomaría el comunismo sería la Sociedad Criolla Dr. Elías Regules, y el puñado de varones que la compone figuraría en las líneas de peligro, llevando bien alto, flameando al lado de nuestra querida bandera nacional nuestro banderín de combate luciendo el lema: Tradición y Patria. ${ }^{28}$
\end{abstract}

Allí la agrupación mostraba su histórico perfil como pocas veces lo había hecho. El refugio de la patria, en el período estudiado, era representado como bastión del anticomunismo. Sus gauchos como soldados dispuestos a confrontar materializando una barrera al avance de esas "ideas disolventes". La escuela, y sus maestros, eran interpelados en la continuidad del discurso para integrarse en

26 (Junio de 1937), Cimarrón, Montevideo, p. 19.

27 Justo Alonso fue un militante del Partido Nacional e integró los consejos directivos en diferentes períodos. Identificado como una de las figuras más destacadas del herrerismo, llegó a la presidencia del directorio del Partido en la década del setenta. Entrevista a Jorge Castiglioni, nieto de Justo Alonso y actual secretario general de la Sociedad Criolla Dr. Elías Regules, realizada por el autor el 24 de julio de 2019.

28 (Diciembre de 1936), Cimarrón, Montevideo, p. 48. 
ese "frente patriótico" impulsado por la agrupación. La alusión seguramente contestaba la proyección opositora de "frentes populares" con representación de todos los partidos enfrentados a la dictadura de Terra.

Posiciones como la de Alonso, que hablaba en representación de la Sociedad Criolla, favorecían la comunión con otras instituciones del Uruguay del treinta, como la Asociación Patriótica. La institución se había fundado en 1915 para contrarrestar los efectos de las tendencias modernizadoras. Carlos Demasi (2004) explica que se trataba de una "redefinición conservadora de la nación" que funcionó como aglutinante del antibatllismo y su "reformismo cosmopolita". En una muestra de la cercanía de objetivos y entendimiento, durante el aniversario número 43 del grupo tradicionalista hizo uso de la palabra el coronel Adolfo Quintana, presidente de la Asociación Patriótica del Uruguay. Allí, subrayó los males que podían arrasar las costumbres nativas, recordó a Regules y celebró la obra de La Criolla por su eficacia en la "acción patriótica". ${ }^{29}$ Las relaciones sociales con otras agrupaciones se fueron extendiendo allende las fronteras y durante la década del cuarenta se estableció un decisivo entramado tradicionalista rioplatense.

\section{El entramado rioplatense y el Día de la Tradición}

La revitalización de la Sociedad Criolla recuperó uno de los aspectos reseñados para los primeros años de su funcionamiento: los lazos con tradicionalistas argentinos que, fuese mediante la producción literaria o la promoción asociativa, manifestaban intereses compartidos con los gauchos de Montevideo. Antes de analizar las características de las conexiones establecidas durante la década del cuarenta y los efectos de esos vínculos en el derrotero del renacer gauchesco uruguayo, es menester indagar en una perspectiva más amplia qué empezaba a esbozarse desde La Criolla.

La operación se puso en marcha interviniendo la efeméride del 25 de mayo que conmemoraba la destitución del virrey Baltasar Cisneros y la formación de la Primera Junta en Buenos Aires. Al momento de la fundación de la asociación tradicionalista, la fiesta seguía formando parte del calendario oficial uruguayo, por lo que dotaba al evento inaugural de una fuerza patriótica singular. Hacia 1936, tanto en los discursos de los aniversarios como en los editoriales de Cimarrón, se fueron extendiendo los límites de la efeméride para catalogarla como el "día de la libertad latinoamericana”. Los puntos de fuga de esa clasificación ameritarían un estudio particular por su densidad; no obstante, para los gauchos se fue cristalizando esa interpretación no solo en lo discursivo sino también en los programas. Con el transcurrir de los años, se fue confundiendo el aniversario de La Criolla con la "Fiesta de América". La bandera con la diagonal de Artigas era secundada por el pabellón de todos los países del continente y, no azarosamente, la asociación de Regules se confirmaba como la máxima expresión del tradicionalismo regional. 
Contenida en la "hermandad continental" que proclamaban desde Uruguay, se encontraba una identificación regional que era celebrada incluso antes de establecer los primeros contactos transnacionales. Cuando aún no tenían injerencia en el diseño competitivo de la Semana Criolla capitalina se reclamaba el convite a los "gauchos porteños", "gauchos correntinos", "gauchos entrerrianos" y "gaúchos riograndenses" para que junto con los auténticos representantes uruguayos dotaran al festival de una legitimidad perdida.

A las referencias abstractas e imprecisas se puede incorporar otro nivel de conexiones, también previo a las relaciones institucionales, ligado al campo literario. En ese sentido, desde Cimarrón se esforzaron por representar al Martín Fierro como una obra "netamente rioplatense" ya que, según la revista, la primera parte había sido escrita en Argentina y la segunda en Uruguay. ${ }^{30}$ Es sabido que el proceso de escritura del poema fue más complejo y que las posiciones políticas de José Hernández fomentaron diversos desplazamientos. Más allá de eso, desde ese enfoque Fierro era asiduamente citado y vitoreado como arquetipo regional. Esa consideración se reproducía en otras voces de la cultura uruguaya como lo testimoniaba el monumento al Viejo Vizcacha, inaugurado en Montevideo en 1930.

Los tradicionalistas se ocuparon de eventos y homenajes realizados al otro lado del Río de la Plata para reseñarlos y comentarlos en las páginas de su órgano oficial. El caso más revisitado durante 1936 fue el de Martiniano Leguizamón, amigo de Elías Regules. En ocasión de la inauguración del Instituto que lleva su nombre en la ciudad de Paraná de su Entre Ríos natal, en Cimarrón se extendía la referencia con poemas en su honor, salutaciones al municipio por la gestión y fotografías del escritor vestido de gaucho. ${ }^{31}$ Leguizamón había sido un contacto permanente para los socios fundadores de La Criolla. A tal punto había llegado esa vinculación que se había convertido en agente de la revista El Fogón. En otro trabajo hemos analizado la influencia de su obra teatral Calandria en los criollistas uruguayos finiseculares. La propuesta de un gaucho readaptado que había dejado el matreraje y se había reinsertado en la sociedad como puestero de estancia fue tomada como modelo por el grupo de Regules. En efecto, la "calandrización" del gaucho se presentó como respuesta a la moreirización tan temida hacia finales del siglo XIX (Casas, 2018).

Otro nivel de vinculaciones se estableció a escala personal e institucional. El contacto más cercano se logró con la Agrupación Bases de La Plata y luego se continuó con la Federación Gaucha Bonaerense. Se trataba de una asociación fundada en 1928 primariamente con fines literarios que fue circunscribiendo sus intereses hacia temáticas gauchescas y tradicionales. No exenta de disputas internas, desplazamientos, vínculos políticos y polémicas públicas, lo cierto es que jugó un rol central en la elaboración y difusión del proyecto para sancionar el Día de la Tradición en la provincia de Buenos Aires, finalmente legislado en 1939 (Casas, 2017). 
El origen de las relaciones con los "básicos" estuvo asentado por la circulación de obras literarias y el flujo de las publicaciones periódicas. Desde mediados de la década del treinta hubo una lectura atenta de los miembros de la Sociedad Criolla ante cualquier lanzamiento vinculado al universo gauchesco. La atención no se reducía a la adquisición del material sino que hacían lo posible para dar cuenta de su conocimiento. Así, cuando la revista Caras y Caretas lanzó una edición especial en homenaje al gaucho de aproximadamente 150 páginas, desde la agrupación uruguaya se envió una carta de felicitación que, como retribución, Caras y Caretas publicó en su número siguiente. Un ejercicio similar se practicaba con los escritores vinculados a Bases de mayor renombre. Justo P. Sáenz (h), por ejemplo, era agasajado con un poema dedicado a rememorar su primera obra, Pasto Puna, publicada con prólogo de Martiniano Leguizamón en 1928. ${ }^{32}$

En 1941 los contactos literarios dieron paso al encuentro personal. En una etapa de expansión de los festejos programados por el Día de la Tradición en Buenos Aires, y de La Plata como sede permanente para los eventos del 10 de noviembre, Agrupación Bases intensificó las invitaciones a delegaciones del interior del país y convidó también a la Sociedad Criolla de Montevideo. Encabezados por Elías Regules (hijo) viajó una delegación de una decena de representantes para desfilar, entonar el himno y celebrar al gaucho en la capital bonaerense. ${ }^{33}$ Descle ese encuentro, las visitas se repetirían año tras año. Los miembros de la Agrupación Bases viajaban a Montevideo en ocasiones para la Semana Criolla y en otras para el aniversario de la Sociedad Elías Regules. Además de las visitas, la consolidación de los lazos entre los tradicionalistas se logró gracias a una cruzada conjunta que emprendieron contra la revista Atlántida, en 1943.

En julio de ese año, un artículo de Pedro Julio Echagüe acusaba al gaucho de “atorrante", explicando que nunca en su vida había trabajado, lo desligaba de los conceptos de familia y hogar y lo reducía a una construcción literaria utilizada como propaganda barata. Pedía concluir con el culto del gaucho ya que "no nos ha servido nunca para nada" y dar fin a las evocaciones de esa "rémora para el progreso". ${ }^{34}$ La reacción del tradicionalismo no se hizo esperar y tuvo como fuerza propulsora a los socios de Bases. Luego de diversos actos de desagravio y cartas a los directivos de la revista y al presidente de la Nación, se decidió la suspensión de la publicación hasta tanto no se corrigieran los conceptos vertidos sobre el símbolo nacional. Los gauchos de la Sociedad Criolla, siempre alerta de las amenazas y ya con vínculos estrechos con los básicos, extendieron la reacción.

Entre otras actividades invitaron a Luis Pinto, gestor de la mayoría de las iniciativas en Buenos Aires, a disertar en Mercedes, Uruguay, donde realizaron una fiesta por lo que se consideraba una nueva victoria del tradicionalismo rioplatense. Al compás de la Agrupación Bases, Tabaré Regules envió una carta a Constancio Vigil, responsable de Atlántida explicándole que el gaucho venerado no se podía perder

32 (Agosto de 1936), Cimarrón, Montevideo.

33 Archivo de Agrupación Bases, Museo Almafuerte, La Plata, Argentina.

34 (Julio de 1943), Atlántida, Buenos Aires, p. 33. 
porque era necesario "enfrentarlo a la ciudad extranjerizada, a la ciudad cosmopolita moderna". ${ }^{35}$ Vigil, en su respuesta, mostraba coincidencias en cuanto al culto al gaucho y afirmaba "a honra lo tenemos". Consideraciones como las de Echagüe les permitía confirmar todos los temores esbozados con respecto a los peligros que acechaban la integridad nacional. A su vez, funcionaban como promotores de nuevos proyectos para extender el cultivo de la tradición hacia toda la región.

Las intervenciones conjuntas se fueron incrementando y de los desfiles, los himnos y las banderas se dio paso a discursos compartidos, intercambio de publicaciones y regalos de accesorios gauchescos. En la Fiesta de la Tradición de 1943, celebrada en La Plata, uno de los oradores principales fue Tabaré Regules, ${ }^{36}$ en el programa de festejos por el aniversario de la Sociedad Criolla en 1944 hizo uso de la palabra Octavio Carlevaro, secretario de la Agrupación Bases. En la correspondencia entre Mario Sureda, uno de los miembros fundadores de la asociación platense y Alberto Rodríguez López, integrante de la Comisión Directiva de La Criolla, el argentino agradecía por los ejemplares de Cimarrón donados para la biblioteca de la institución y prometía difundirlos entre sus integrantes. También confirmaba que Justiniano de la Fuente, presidente de la Federación Gaucha Bonaerense, había quedado tan a gusto con el juego de platería obsequiado por los uruguayos que los trasladaba a cada comida social. ${ }^{37}$ Si eso no bastaba para rememorar la comunión entre los tradicionalistas del Plata, en Cimarrón dedicaban semblanzas y poemas a sus "colegas" argentinos entre los que se destacaban las dedicatorias al "patriarca Santiago Rocca", una de las figuras más relevantes del resurgimiento gauchesco en Buenos Aires.

Las conexiones con el grupo de gauchos cercanos a Bases no fueron las únicas en el entramado generado desde la Sociedad Criolla. A partir de las páginas de Cimarrón entraron en contacto con Carlos Daws, otro de los nombres propios destacados en la capital argentina a partir de la composición de su afamado museo gauchesco. ${ }^{38}$ También las giras de las compañías teatrales que podrían aproximarse a temáticas criollas funcionaron como nodos en las redes vinculares. Ese fue el caso de las producciones de Muiño-Alippi, destacados a partir de la representación exitosa de Lo que le pasó a Reynoso, obra escrita por Alberto Vaccarezza. En su visita a Montevideo, les realizaron un almuerzo campero en la agrupación y les agradecieron por "desintoxicar" el teatro nacional tan maleable al "cosmopolitismo más heterogéneo". ${ }^{39}$

La impronta argentina en los eventos del tradicionalismo uruguayo tuvo su apogeo en dos eventos contemporáneos: la inauguración de la nueva sede social y los intercambios para elaborar un proyecto que instituyera el Día de la Tradición en el Uruguay. El 25 de mayo de 1944 se inauguró oficialmente el local ubicado en

35 (Edición especial, 1944), Cimarrón, Montevideo, p. 59.

36 (12 de noviembre de 1943), El Argentino, La Plata, p. 4.

37 (Edición especial, 1944), Cimarrón, Montevideo.

38 (Septiembre de 1938), Cimarrón, Montevideo.

39 (Diciembre de 1936), Cimarrón, Montevideo, p. 51. 
la avenida Bolivia que se mantiene hasta la actualidad. El edificio contaba con un casco de estancia que luego se fue expandiendo para incorporar una pulpería y una capilla. Las proyecciones de mudanza habían estado azuzadas como parte fundamental de la revitalización de la sociedad. A menudo expresaban públicamente la necesidad de un terreno más amplio para la organización de sus fiestas y actividades ecuestres. ${ }^{40}$

Con el lanzamiento de la "Campaña pro cruzada tradicionalista" se habían recaudado fondos proyectando la nueva adquisición que, si bien inaugurada oficialmente, restaba por construirse en su mayor parte. No obstante, se escogió la fecha del 50o aniversario para la presentación pública de un nuevo signo del resurgimiento criollo. La intendencia de Montevideo, dirigida por Juan Pedro Fabini, participó del evento a través de su secretario Rómulo Botta. Los políticos del Partido Colorado, de filiación batllista, afirmaban que: "En La Criolla sienten el recuerdo afectuoso los gauchos que pasaron y en ella se recoge como el eco permanente de la patria que han formado"..$^{41}$ En comunión, desde el diario El Día se expresaba sobre el gaucho: "No fue nunca un sujeto viciado por defectos, un malevo, un bandolero, como algunos han pretendido juzgar".42 Junto con la representación de la intendencia, la delegación de tradicionalistas argentinos celebraron el evento y le otorgaron al programa oficial una connotación de triunfo regional. Nuevamente las banderas, los himnos, los desfiles y los discursos confirmaban que se trataba de un renacimiento gauchesco en ambos países.

A la vez que la representación del Partido Colorado se hizo presente para saludar a los gauchos de la agrupación, un diputado del Partido Nacional elaboraba junto con los responsables de la Comisión Directiva el proyecto para establecer el Día de la Tradición. La idea de fijar una fecha en el calendario para celebrar anualmente las "costumbres nacionales" no era una ocurrencia del grupo de Tabaré Regules. Su padre ya lo había expresado en diferentes oportunidades e incluso había propuesto el 28 de febrero, día del Grito de Asencio, como ocasión pertinente. ${ }^{43}$

La experiencia en Buenos Aires con respecto al proyecto para instituir la efeméride fue decisiva en el proceso uruguayo. Así lo reconocían los miembros de La Criolla que al publicar una edición especial de Cimarrón por las bodas de oro explicaban la marcha del proyecto. La primera referencia era una carta de Justiniano de la Fuente, miembro de Bases y orador principal de la primera Fiesta de la Tradición en Buenos Aires. Estaba dirigida a todos los socios de la agrupación y contenía una arenga virulenta. Luego de reconocer los monumentos al gaucho y a la carreta, tan envidiados por los bonaerenses, les explicaba: "A ustedes les falta completar la obra, obteniendo como nosotros que la Legislatura del Uruguay, en una ley que le dará jerarquía instituya el Día de la Tradición en toda la

40 (Junio de 1937), Cimarrón, Montevideo.

41 (Edición especial, 1944), Cimarrón, Montevideo, p. 64.

42 (29 de octubre de 1944), El Día, suplemento dominical, Montevideo.

43 (Noviembre de 1937), Cimarrón, Montevideo. 
República”. ${ }^{44}$ En efecto, el logro de los básicos se circunscribía a la provincia de Buenos Aires y la extensión nacional conformaba un objetivo perseguido pero no alcanzado. Más allá de eso, en Montevideo se reflejaba como una victoria nacional.

De la Fuente les trasladaba su intransigencia con respecto a las urgencias de la hora:
Tienen que hacerlo de inmediato, robándole horas al sueño, a la tranquilidad, a la comodidad, al bienestar, a la compañera y a los hijos [...] Tienen que salir a la calle, hablar sin cesar, hablar hasta durmiendo, convertir en obsesión la idea de hacer el Día de la Tradición, despotricar contra los enemigos de la Patria, insultar a los traidores, execrar a los snobistas [...] Hay que ir a la Legislatura con el petitorio en mano [...] Esto hay que hacerlo cueste lo que cueste, aunque vayan a parar a un manicomio... ${ }^{45}$

Dos lecturas habilita la radicalidad del tradicionalista argentino, por un lado la inminente profilaxis cultural que pregona en detrimento de aquellos que se mostraban reticentes a sus ideas. Es válido subrayar que su percepción al respecto no parecía necesitar mayores explicaciones sino que De la Fuente se amparaba en una perspectiva social compartida con los gauchos uruguayos. Por otro lado, la urgencia también respondía al resplandor del movimiento tradicionalista rioplatense. La fuerza conjunta les otorgaba un envión crucial para iniciativas como la presentada.

Las exhortaciones no se agotaron en la pertinencia del momento sino que se ampliaron hasta la postulación de la fecha propicia para celebrar la tradición. En ese punto, el autor se mostraba irreductible y exigía la declaración del 21 de marzo en honor al natalicio de Elías Regules. Sugería establecer ese día en el proyecto para que no quedara a consideración de la Legislatura. Nuevamente se proponía como ejemplo la trayectoria de Bases y la gestión de sus miembros que habían cristalizado cada 10 de noviembre para celebrar al gaucho en Buenos Aires.

La sombra del Día de la Tradición al otro margen del Río de la Plata se manifestó también en los argumentos presentados por el Diputado por el Departamento de Soriano, José Olivera Ubios. El político del Partido Nacional había entrado en contacto con los integrantes de la Sociedad Criolla gracias a las fiestas que organizaban en Mercedes, capital departamental. Los unía, en términos generales, la afición a las prácticas ecuestres, las preocupaciones por el mundo rural y una profunda admiración a Elías Regules. Olivera Ubios había sido su alumno en la Facultad de Medicina donde se egresó como cirujano. En términos particulares, una identificación partidaria con el herrerismo.

Ante el petitorio de la agrupación, el diputado blanco elevó el proyecto a la Legislatura en diciembre de 1943. Luego de hacer hincapié en la "exaltación simbólica del gaucho", el político explicaba los motivos para aprobar la nueva efeméride: "Si

44 (Edición especial, 1944), Cimarrón, Montevideo, p. 17.

45 (Edición especial, 1944), Cimarrón, Montevideo, p. 17-18. 
la Argentina ha fijado el Día de la Tradición el 10 de noviembre...¿No hemos de establecer a la vez nuestro DÍA DE LA TRADICIÓN en una fecha memorable y significativa tal aquella el 21 de marzo.... ${ }^{46}$ Se intentaba, de acuerdo a sus argumentaciones, establecer un día al año para hacer "un alto en la marcha” citadina y rememorar a la tradición nacional que, indefectiblemente, se entendía gauchesca.

En mayo de 1944 el proyecto fue aprobado por la Cámara de Diputados. La Sociedad Criolla Elías Regules culminaba la celebración de sus 50 años dando pruebas contundentes de su triunfo. El regocijo no era solo uruguayo. Los tradicionalistas argentinos enviaron un comunicado de júbilo por la noticia. Finalmente, el Día de la Tradición Uruguaya se sancionó por ley en 1946 y se festejó por primera vez en 1947 con la participación de veinte filiales de La Criolla de distintos departamentos del país que se aunaron a lo gauchos argentinos en Montevideo.

\section{Conclusiones}

La revisión sobre los tiempos fundacionales y el resurgimiento de la Sociedad Criolla en la década del treinta permiten esclarecer una serie de características internas de la agrupación y, desde una perspectiva más amplia, aspectos singulares de la sociedad uruguaya del período. Como se reseñó para los primeros años de actividad, la asociación adquirió un perfil reactivo primero ante los efectos "perniciosos" del proceso de modernización y luego ante las críticas recibidas por los desfiles gauchescos. Ante esa coyuntura, Elías Regules se esforzó por resaltar todos sus pergaminos de civilidad y extenderlos hacia la agrupación. Así se configuró un grupo de tradicionalistas con peculiares puntos de encuentro con los usos y costumbres de la Montevideo del siglo XX, como se vio para el caso del tango.

Las primeras décadas también cristalizaron la narrativa construida desde la propia asociación. En esos relatos se puso énfasis en los componentes insoslayables de su historia: el patriarcado de Elías Regules; el enfrentamiento con los "antipatria” que los cuestionaban; la ligazón con los próceres de la historia tradicional uruguaya; las embrionarias relaciones con la Argentina; y, sobre todo, la interpretación triunfalista de sus recorridos. El esquema establecido se actualizó durante los años treinta. Para ese caso se resucitaron viejos fantasmas y se incorporaron otros pero la estructura de la narrativa permaneció inalterada.

El golpe de Estado de 1933 ofreció un contexto inmejorable para que emergieran las reivindicaciones gauchescas. La confrontación con el batllismo, la cruzada contra el comunismo, el impulso a las actividades rurales, y la cercanía de algunos miembros de La Criolla con los sectores gobernantes brindaron el marco ideal para que la agrupación recuperara los bríos de los comienzos. El Uruguay gaucho se hizo sentir también en otras instituciones y actividades oficiales, como 
el pabellón que presentó el país oriental en la Exposición Internacional de París en 1937 o las colecciones gauchescas que ingresaron al Museo Histórico Nacional para la época (Calvar Agrelo, 2007).

Los amenazas que tanto el Gobierno como los tradicionalistas enunciaban exacerbó los proyectos para extender los campos de acción de la Sociedad Criolla. La premisa de engrosar sus filas y las diversas propuestas para intervenir públicamente generaron un tránsito expansivo del que Cimarrón fue agente indispensable. La reciprocidad alcanzada con otras agrupaciones, como la Asociación Patriótica, dio cuenta de la inserción de La Criolla en un entramado político-ideológico que trascendía por mucho el culto al gaucho y la tradición. El discurso de Justo Alonso en tándem con el presidente del Consejo de Instrucción Primaria fue testimonio de esos intereses compartidos.

Los uruguayos no estuvieron solos en la campaña. Como se revisó en distintas escalas, los tradicionalistas argentinos fueron tomando una relevancia mayor a medida que se expandía el resurgimiento de la asociación. En Buenos Aires habían experimentado un proceso similar apuntalado por distintas agrupaciones, de las que Bases se había destacado por promover la institución del Día de la Tradición. Fueron miembros de esa sociedad los que gestaron un acercamiento estrecho aunando proyectos, defensas y actividades con los "gauchos" de Montevideo. El corolario fue la concepción de la nueve efeméride uruguaya finalmente fijada para cada 21 de marzo en conmemoración de Elías Regules. El movimiento tradicionalista rioplatense demostró su vigor sin perder de vista la proyección continental. El renacer gaucho en la región interpelaría, también, a otras latitudes americanas atravesadas por los mismos "peligros". 


\section{Bibliografía}

" Achúgar, H. (1980). Modernización y mitificación: el lirismo criollista en el Uruguay entre 1890 y 1910. Ideologies and Literature, 3 (14), pp. 134-154.

" Adamovsky, E. (2019). El gaucho indómito. De Martín Fierro a Perón el emblema imposible de una nación desgarrada. Buenos Aires: Siglo Veintiuno Editores.

" Barrán, J. (2004). Los conservadores uruguayos (1870-1933). Montevideo: Ediciones de la Banda Oriental.

" Carámbula de Barreiro, M. (1987). Elías Regules (1861-1929). Revista del Sindicato Médico del Uruguay, pp. 7-13.

" Caetano, G. (1992). Notas para una revisión histórica sobre la cuestión Nacional en el Uruguay. Revista de Historia, (3) , pp. 59-78.

" Caetano, G. (2010). Ciudadanía y nación en el Uruguay del Centenario (1910-1930). La forja de una cultura estatista. Iberoamericana, X, (39), pp. 161-176.

"Calvar Agrelo, D. (2007). El pabellón uruguayo en la Exposición de París de 1937 y la propaganda terrista. Coloquio 70 Aniversario del Guernica de Picasso y la Exposición de París de 1937.

" Casas, M. (2018). El Fogón, periódico criollo: tiempos fundacionales, sociedad y reformulaciones sobre el criollismo finisecular rioplatense (1895-1896). Claves. Revista de Historia, 4 (6), pp. 153-190.

"Casas, M. (2017). Las metamorfosis del gaucho: círculos criollos, tradicionalistas y política en la Provincia de Buenos Aires, (1930-1960). Buenos Aires: Prometeo Editorial.

"Casas, M. (2016). Entre peronistas y radicales: disputas en torno al monumento al gaucho en la provincia de Buenos Aires, 1947-1948. Prohistoria, 25 (19), pp. 53-78.

" Cattaruzza, A. y Eujanian, A. (2002). Del éxito popular a la canonización estatal del Martín Fierro. Tradiciones en pugna (1870-1940). Prismas, 4, pp. 97-120.

"Demasi, C. (2004). La lucha por el pasado: historia y nación en Uruguay: 1920-1930. Montevideo: Ediciones Trilce.

"Fradkin, R. (2003). Centaures de la Pampa. Le gaucho entre I'histoire et le mythe. Annales HHS, 1 (58), pp. 109-133.

" Giaudrone, C. (2008). El gaucho en el ámbito iconográfico del centenario uguayo (19251930). Revista Hispánica Moderna, 61 (2), pp. 149-165.

" González Laurino, C. (2001). La construcción de la identidad uruguaya. Montevideo: Ediciones Santillana - Universidad Católica del Uruguay.

"Iturria, R. (2014). Elías Regules. De la tapera a la criolla. Montevideo: Ediciones de la Plaza.

" Lago, T. (1953). El huaso. Ensayo de antropología social. Santiago de Chile: Ediciones de la Universidad de Chile.

" Jacob, R. (1983). El Uruguay de Terra, 1931-1938. Montevideo: Ediciones de la Banda Oriental.

" Lehmann Nitsche, R. (1917). Santos Vega. Buenos Aires: Imprenta de Coni Hermanos.

" Moreno Chá, E. (2016). "Aquí me pongo a cantar" El arte payadoresco de Argentina y Uruguay. Buenos Aires: Editorial Dunken. 
" Palomar Verea, C. (2004). En cada charro un hermano. La charrería en el Estado de Jalisco. Jalisco: Secretaría de Cultura, Gobierno del Estado de Jalisco.

" Pérez Montfort, R. (2003). Estampas de nacionalismo popular mexicano. Diez ensayos sobre cultura popular y nacionalismo. Ciudad de México: Centro de Investigaciones y Estudios Superiores en Antropología Social.

" Porley, C. (2019). El coleccionista. Fernando García y su legado al Estado uruguayo. Montevideo: Editorial Estuario.

"Prieto, A. (1988). El discurso criollista en la formación de la Argentina moderna. Buenos Aires: Sudamericana.

"Rama, A. (1976). Los gauchipolíticos rioplateneses. Montevideo: Calicanto Editorial.

"Rocca, P. (2000). El campo y la ciudad en la narrativa uruguaya (1920-1950). Fragmentos, Revista de lingua y literatura estrangeiras da Universidade Federal de Santa Catarina, (19), pp. 7-28.

" Rodríguez Ayçaguer, A. (2008). La República del compromiso. 1919-1933. En Frega, A. et al. Historia del Uruguay en el siglo XX (1890-2005). Montevideo: Ediciones de la Banda Oriental, pp. 51-84.

" Ruiz, E. (2008). Del viraje conservador al reordenamiento internacional. 1933-1945. En Frega, A. et al. Historia del Uruguay en el siglo XX (1890-2005). Montevideo: Ediciones de la Banda Oriental, pp. 85-121.

" Silva Valdés, F. (1960). El teatro uruguayo contemporáneo. Madrid: Aguilar.

" Sociedad Criolla (1919). Sus bodas de Plata. Montevideo: Talleres Gráficos A. Barreiro y Ramos.

"Sociedad Criolla (1928). Estatutos. Montevideo: Talleres Gráficos A. Barreiro y Ramos.

"Sociedad Criolla Dr. Elías Regules (1991). Libro Institucional. Montevideo.

" Sociedad Recreativa de los 33. (1894). Reglamentos. Montevideo: Imprenta El Siglo Ilustrado.

" Tomeo, D. (2015). Los caminos que llevaron a Artigas a la plaza Independencia. Cuadernos del CLAEH, 34 (102), pp. 69-90.

"Zalla, J. (2018). O centauro e a Pena. Barbosa Lessa e a invenção das tradições gaúchas. Porto Alegre: Editora da UFRGS.

" Zum Felde, A. (1941). Proceso intelectual del Uruguay. Montevideo: Editorial Claridad. 